Original Research Paper

\title{
Pemanfaatan Bahan Organik Sebagai Solusi Solum Tanah Dangkal di Desa Slateng Kecamatan Ledokombo Kaki Gunung Raung
}

\author{
Basuki $^{1}$, Vega Kartika Sari², Marga Mandala ${ }^{3}$ \\ ${ }^{1}$ Program Studi Ilmu Tanah Fakultas Pertanian, Universitas Jember, Jember, Indonesia; \\ ${ }^{2}$ Program Studi Agronomi Fakultas Pertanian, Universitas Jember, Jember, Indonesia; \\ ${ }^{3}$ Program Studi Ilmu Tanah Fakultas Pertanian, Universitas Jember, Jember, Indonesia.
}

https://doi.org/10.29303/jpmpi.v3i2.1407

Sitasi: Basuki., Sari, V. K \& Mandala, M. (2022). Pemanfaatan Bahan Organik Sebagai Solusi Solum Tanah Dangkal di Desa Slateng Kecamatan Ledokombo Kaki Gunung Raung. Jurnal Pengabdian Magister Pendidikan IPA, 5(1)

\section{Article history \\ Received: 11 Januari 2022 \\ Revised: 11 Februari 2022 \\ Accepted: 27 Februari 2022 \\ *Corresponding Author: \\ Basuki, Program Studi Ilmu \\ Tanah Fakultas Pertanian \\ Universitas Jember, Jember, \\ Indonesia; \\ Email: basuki@unej.ac.id}

\begin{abstract}
Slateng village is located at the western foot of Mount Raung in Ledokombo District, Jember Regency. Farming and cattle ranching provide the majority of the people's income. Agricultural land productivity is still low compared the production standard based on plant variety descriptions. The cultivated land has shallow solum. This activity aims to provide training for Slateng's farmer to boost cultivated plant yield by enhancing the properties of shallow solum soil and producing organic fertilizer from agricultural waste. Socialization and practice are the methods employed for this activity. The increased of participants' knowledge grew from $30 \%$ to $100 \%$ as a result of the exercise. Participants were quite interested with the training on creating organic fertilizers, which required active participation from participants, particularly farmers, with a satisfaction rate of $90 \%$. This community service activities can help increase the production of cultivated plants, particularly on marginal land with shallow solum soil.
\end{abstract}

Keywords: Slateng, shallow solum, organic matter, increased production

\section{Pendahuluan}

Produktifitas lahan sangat penting dalam mendukung hasil budidaya tanaman yang tumbuh diatasnya. Parameter lahan yang berpengaruh terhadap jumlah hasil tanaman diantaranya unsur hara, solum tanah, tekstur tanah, kelerengan, kondisi air pengairan (Basuki and Sari, 2020). Tanaman tumbuh membutuhkan unsur hara yang komplek baik unsur hara makro, mikro, maupun unsur hara ensensial lainnya. Unsur hara merupakan unsur hara yang diserap oleh tanaman jumlahnya banyak. Kekurangan unsur hara makro akan menunjukkan gejala defisiensi dan secara langsung berpengaruh terhadap hasil yang diharapkan. Unsur hara makro terbagi atas makro primer seperti unsur hara nitrogen, pospor, kalium, dn unsur hara makro sekunder seperti calsium, magnesium, sulfur, dan natrium(Sukri et al. 2020). Tanaman padi dalam satu siklus tumbuh untuk menghasilkan rata-rata 6 ton/ha gabah menyerap unsur hara makro sebesar $165 \mathrm{~kg} /$ ha nitrogen, 19 $\mathrm{kg} / \mathrm{ha}$ pospor, dan $112 \mathrm{~kg} / \mathrm{ha}$ kalium (Basuki et al., 2021). Tanaman selain membutuhkan unsur hara makro juga menyerap unsur hara mikro dengan jumlah yang sedikit dan bilamana terjadi kekurangan terjadi defisiensi dan bila kelebihan terjadi keracunan(Basuki et al. 2015).

Tanaman menyerap unsur hara dalam koloid tanah melalui rambut akar. Sistem perakaran berpengaruh terhadap jumlah hara yang diserap tanaman. Semakin panjang dan semakin lebar jangkauan perakaran baik vertical maupun 
horizontal semakin banyak unsur hara yang diserap tanaman dan sebaliknya. Jangkauan perakaran dipengaruhi oleh kondisi tebal kedalaman atau solum. Tanaman padi membutuhkan solum tanah minimal $50 \mathrm{~cm}$ untuk mendukung pertumbuhan dan produktifitas(Ratriyanto et al. 2019).

Pulau Jawa dibentuk oleh aktifitas tenaga endogen dan eksogen yang membentuk gunung api mulai dari daru ujung timur sampai ujung barat (Brahmantyo and Salim 2006). Keberadaan gunung api membentuk kondisi lahan yang berbeda (Sukarman et al., 2020; Wibisono, 2021). Gunung Raung di Jawa Timur yang secara administrasi berada di Kabupaten Banyuwangi dan Kabupaten Jember. Desa Slateng merupakan desa yang berada di wilayah barat Gunung Raung yang berada di wilayah Kecamatan Ledokombo Kabupaten Jember dengan topografi lahan datar berlereng. Penggunaan lahan wilayah Desa Slateng terutama untuk pertanian dimanfaatkan untuk komoditas tanaman pangan, hortikultura, dan tanaman perkebunan. Tanaman pangan yang di budidayakan meliputi padi, jagung, kedelai; tanaman hortikultura yang dibudidayakan seperti kubis, cabai, tomat; dan tanaman tembakau seperti tembakau. Produktifitas tanaman yang ditanam di wilayah ini masih dibawah produktifitas dalam diskripsi varietas karena solum tanah. Solum tanah sebagian besar wilayah Desa Slateng dalam kategori dangkal dibawah $50 \mathrm{~cm}$, dan bahkan terdapat lahan yang solum tanah $10 \mathrm{~cm}$. Solum tanah yang dangkal mempengaruhi kesejahteraan petani terutama di Desa Slateng karena antara input yang dikeluarkan dengan output hasil pertanian yang dihasilkan tidak seimbang dan bahkan merugi(Sari et al. 2021).

Mata pencaharian penduduk Desa Slateng selain bertani yaitu berternak, dengan ternak utama sapi potong, kambing, dan domba (Basuki, Novikarumsari, et al. 2021; Sari et al. 2021). Sapi per ekor dalam sehari mampu menghasilkan kotoran segar sebanyak $25 \mathrm{~kg}$, dan $10 \mathrm{~kg}$ dalam kondisi kering. Tahun 2021 jumlah sapi di Kecamatan Ledokombo 10.802 ekor, kambing 2.484 ekor, domba 2.988 ekor (BPS 2021). Kotoran ternak dapat dijadikan sebagi bahan organik yang mampu meningkatkan produktifitas tanaman memalui perbaikan carbon organik tanah dan mampu mendukung perbaikan sifat fisik tanah terutama tanah dengan solum dangkal. Kegiatan pengabdian masyarakat di Desa Slateng Kecamatan Ledokombo Kabupaten Jember dilaksanakan dengan tujuan untuk meningkatkan produktifitas tanaman budidaya melalui perbaikan karakteristik tanah solum dangkal dengan pembuatan pupuk organik dari limbah pertanian.

\section{Metode}

\section{Tempat dan Waktu Pelaksanaan}

Kegiatan pengabdian masyarakat dilaksanakan di Desa Slateng Kecamatan Ledokombo Kabupaten Jember. Waktu pelaksanaan pengabdian masyarakat pada Bulan Januari Tahun 2022.

\section{Sasaran Pelaksanaan}

Kegiatan pengabdian masyarakat di Desa Slateng Kecamatan Ledokombo dengan sasaran yaitu petani muda terutama yang antusias terhadap teknologi pertanian dalam meningkatkan kesejahteraan melalui perbaikan kualitas tanah.

\section{Metode dan Pendekatan Pelaksanaan}

Metode yang digunakan dalam menyampaikan ilmu dan teknologi melalui penyuluhan dan pelatihan dengan tahapan meliputi persiapan, pelaksanaan kegiatan, dan evaluasi kegiatan yang dapat dijabarkan sebagai berikut:

\section{Persiapan kegiatan}

Persiapan kegiatan meliputi penentuan jadwal dengan mitra, penentuan tempat penyuluhan dan pelatihan, pembagian alat dan bahan yang digunakan dalam pelatihan antara mitra dengan pelaksana kegiatan, pengumpulakn alat dan bahan yang akan digunakan baik mitra maupun pelaksana kegiatan.

\section{Pelaksanaan kegiatan}

Kegiatan pengabdian dilaksanakan terbagi atas dua kegiatan yaitu penyuluhan dan pelatihan (Setiawati et al., 2019). Adapun rincian masingmasing kegiatan sebagai berikut:

a. Penyuluhan, dilakukan dengan memberi materi terkait pemanfaatan limbah pertanian dan peternakan, peran kualitas tanah dalam mendukung peningkatan produktifitas tanaman. Evaluasi kegiatan tertulis dalam bentuk pre/post-test.

b. Pelatihan, dilakukan praktek pengolahan limbah pertanian dan peternakan sebagai sumber bahan organik dalam meningkatkan sumber carbon organik dan mengatasi solum tanah yang dangkal.

c. Pendampingan, kegiatan pendampingan dilaksanakan dengan membuka konsultasi 
baik secara tatap muka, maupun melalui media mensos sebagai sarana peningkatan kualitas dari kegiatan pengabdian masyarakat.

\section{Evaluasi kegiatan}

Dalam rangka mengetahui pemahaman peserta/ mitra terhadap materi yang diberikan perlu dilakukan evaluasi kegiatan (Basuki et al., 2021). Evaluasi kegiatan berupa wawancara, dan evaluasi tertulis dalam bentuk pre/post-test dilakukan pada sesi awal dan akhir kegiatan (Basuki, Novikarumsari, et al. 2021; Sari et al. 2021).

\section{Hasil dan Pembahasan}

Penyuluhan terkait pemanfaatan limbah pertanian dan peternakan, peran kualitas tanah dalam mendukung peningkatan produktifitas tanaman dilaksanaka pada minggu pertama bulan Januari tahun 2022. Lokasi tempat penyuluhan di rumah warga yang sekaligus peserta ikut dalam kegiatan penyuluhan. Kegiatan penyuluhan dihadiri oleh 10 orang peserta. Susunan acara kegiatan penyuluhan meliputi pembukaan, pembacaan doa, pretest, pemaparan materi, diskusi, posttest, dan penutup. Pemaparan materi disambut antusias peserta penyuluhan saat sesi diskusi. Diskusi berjalan secara aktif melalui tanya jawab. Diskusi mengenai peran bahan organik, kualitas tanah, pupuk dan pemupukan, varietas tanaman padi, dan cara mengelola tanah dengan solum dangkal. peserta aktif dalam kegiatan diskusi dengan $80 \%$ peserta penyuluhan menyampaikan pertanyaan. Kegiatan penyuluhan dan sosialisasi tidak akan efektif bilamana tidak ada keaktifan dari peserta dalam menyampaikan pendapat. Kegiatan pemaparan materi disajikan pada Gambar 1.

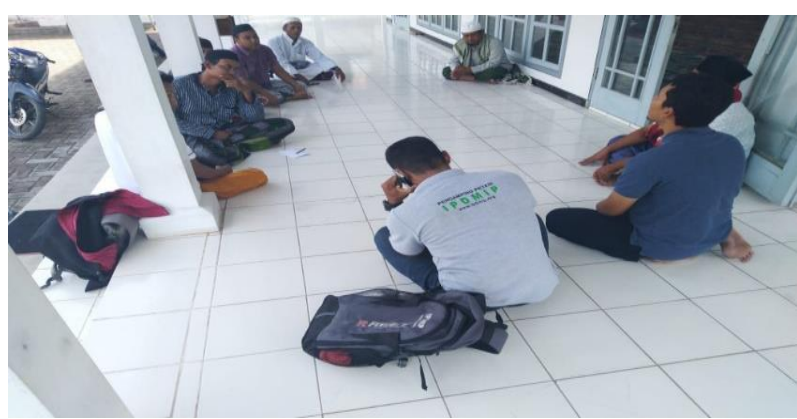

Gambar 1. Penyuluhan dan diskusi terkait pemanfaatan limbah pertanian dan peternakan, peran kualitas tanah dalam mendukung peningkatan produktifitas tanaman
Evaluasi kegiatan secara tertulis dilakukan melalui pretest dan postest. Kegiatan pre test dan post test meliputi 4 pertanyaan sebagaimana disajikan pada Tabel 1. Pada tabel tersebut menunjukkan bahwa pengetahuan rata-rata peserta terkait pemanfaatan limbah pertanian dan peternakan, peran kualitas tanah dalam mendukung peningkatan produktifitas tanaman sebelum dilakukan penyuluhan dan diskusi sebesar 30\% sudah mengetahui, tetapi $70 \%$ belum mengetahui. Pertanyaan 1 terkait dengan pengetahuan limbah pertanian dan peternakan bisa digunakan sebagai peningkat kualitas tanah hanya $30 \%$ yang mengetahui dan sisanya belum mengetahui. Pertanyaan 2 terkait pemahaman peserta dalam pembuatan pupuk organik dengan pemanfaatan decomposer dari luar hanya $20 \%$ yang mengetahui. Pertanyaan 3 terkait bahan pemerkaya pupk organik hanya $40 \%$ yang mengetahui. Pertanyaan 4 terkait dengan bahan organik mampu meningkatkan kualitas tanah pada lahan marginal, contoh tanah dengan solum dangkal $(10 \mathrm{~cm})$ hanya $30 \%$ yang mengetahui. Akhir dari kegiatan penyuluhan dilakukan post test, dan diperoleh $100 \%$ peserta mengetahui pemanfaatan limbah pertanian dan peternakan, serta peran kualitas tanah dalam mendukung peningkatan produktifitas tanaman. Penggunaan bahan organik mampu meningkatkan produksi tanaman padi $30 \%$ pada tanah tangkal karena dengan bahan organik sumber nutrisi meningkat, daya menimpan air meningkat, dan daya jangkar akar luas(Wardani et al. 2019).

Tabel 1. Hasil evaluasi kegiatan terkait pemanfaatan limbah pertanian dan peternakan dalam mendukung peningkatan produktifitas tanaman.

\begin{tabular}{|c|c|c|c|c|c|}
\hline \multirow[t]{2}{*}{ No. } & \multirow[t]{2}{*}{ Pertanyaan } & \multicolumn{2}{|c|}{$\begin{array}{c}\text { Pre Test } \\
(\%)\end{array}$} & \multicolumn{2}{|c|}{$\begin{array}{c}\text { Post Test } \\
(\%)\end{array}$} \\
\hline & & ya & tidak & ya & tidak \\
\hline 1 & $\begin{array}{l}\text { Apakah anda mengetahui } \\
\text { bahwa limbah pertanian } \\
\text { dan peternakan bisa } \\
\text { digunakan sebagai } \\
\text { peningkat kualitas tanah }\end{array}$ & 30 & 70 & 100 & 0 \\
\hline 2 & $\begin{array}{l}\text { Apakah pernah cara } \\
\text { membuat pupuk organik } \\
\text { dengan cara pemanfaatan } \\
\text { decomposer dari luar }\end{array}$ & 20 & 80 & 100 & 0 \\
\hline 3 & $\begin{array}{l}\text { Apakah anda tahu bahan } \\
\text { apa saja yang digunakan } \\
\text { untuk memperkaya bahan }\end{array}$ & 40 & 60 & 100 & 0 \\
\hline
\end{tabular}




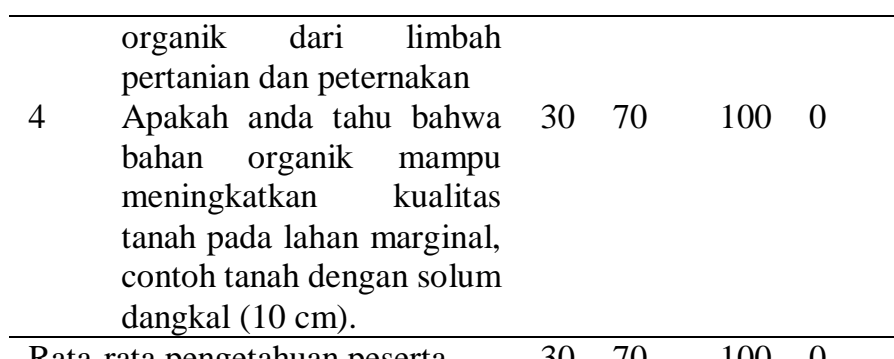

$\begin{array}{lllll}\text { Rata-rata pengetahuan peserta } & 30 & 70 & 100 & 0\end{array}$

Sumber: hasil evaluasi kegiatan (pre test dan post test)

Pelatihan pemanfaatan limbah pertanian dan peternakan sebagai sumber bahan organik dalam meningkatkan sumber carbon organik dan mengatasi solum tanah yang dangkal dilakukan pada minggu ke tiga dan minggu ke empat. Pelatihan dihadiri oleh 13 perserta dengan usia antara 20-45 tahun. Pelatihan pembuatan pupuk organik menggunakan peran aktif peserta yang dalam hal ini peserta terjun langsung dalam praktek. Susunan acara dalam kegiatan praktek pembuatan pupuk organik antara lain pembukaan, doa bersama, pemaparan langkah kerja, praktek dan pendampingan, dan terakhir penutup. Adapun Langkah kerja dalam pembuatan pupuk organik yang dilakukan meliputi:

1. Alat

Alat yang digunakan dalam praktek pembuatan pupuk organik antara lain:
a. Terpal
b. Cangkul/ sekop
c. Timbangan
d. Gembor
e. Ember

2. Bahan

Bahan yang digunakan dalam praktek pembuatan pupuk organik antara lain:
a. Kotoran sapi setengah matang
b. Bekatul
c. Dolomit
d. Abu
e. Urin sapi
f. $\mathrm{Em} 4$
g. Tetes
h. Air secukupnya

3. Langkah kerja

Langkah kerja dalam pembuatan pupuk organik antara lain:

a. Menimbang bahan kotoran sapi $100 \mathrm{~kg}$, dolomit $3 \mathrm{~kg}$, bekatul $5 \mathrm{~kg}$, abu $20 \mathrm{~kg}$ dan menaruh diatas terpal dan dicampur menggunakan sekop atau cangkul. b. Menimbang urin sapi sebanyak 2 liter, EM4 1 liter, tetes 1 liter, dan ldicampur dalam ember dengan ditambahkan air secukupnya sehingga menjadi larutan dekomposer.

c. Memindahkan larutan decomposer ke dalam gembor dan mengkocorkan ke bahan yang ada di terpal secara merata.

d. Mengaduk bahan yang sudah diberi larutan decomposer dengan sekop/cangkul.

e. Menutup dengan terpal selama 7-14 hari agar pupuk organik terdekomposisi sempurna.

f. Mengecek kualitas pupuk organik yang sudah bisa digunakan dengan mengambil dan memegang campuran bahan bila tidak hangat maupun bau.

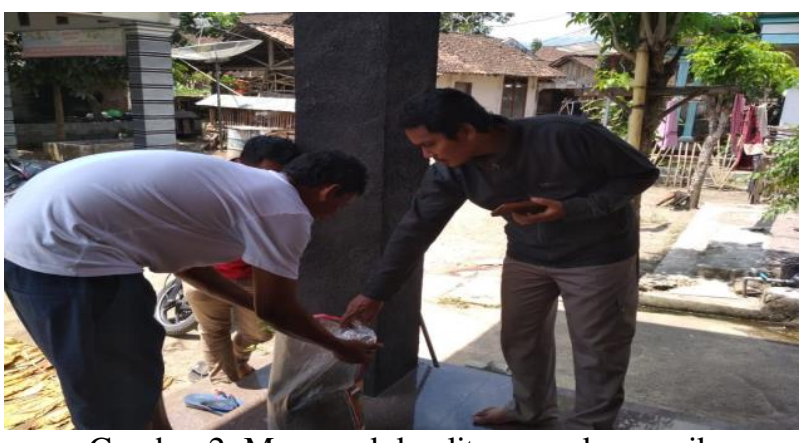

Gambar 2. Mengecek kualitas pupuk organik

Evaluasi kegiatan juga dilakukan melalui kegiatan wawancara. Adapun tingkat kepuasan dan tindak lanjut ke depat terkait kegiatan pengabdian ini dapat dilihat pada Tabel 2. Parameter evaluasi kegiatan meliputi materi kegiatan, manfaat kegiatan, dan keberlanjutan program. Tabel 2. Menunjukkan bahwa tingkat kepuasan yang diberikan untuk mendukung kesejahteraan masyarakat terutama dalam meningkatkan produktifitas tanaman budidaya di lahan dengan solum dangkal melalui penggunaan bahan organik $80 \%$ menyatakan sangat puas, $10 \%$ puas , dan $10 \%$ menyatakan cukup puas. Parameter kedua yaitu terkait manfaat program kegiatan $90 \%$ menyatakan sangat puas, dan $10 \%$ menyatakan puas. Parameter terakhir dalam evaluasi program yaitu keberlanjutan program dan $100 \%$ dari peserta menyatakan sangat puas bilamana program ini dilaksanakan selanjutanya. 
Tabel 2. Evaluasi kegiatan Pengabdian Masyarakat

\begin{tabular}{llllll}
\hline No. & Evaluasi & \multicolumn{4}{c}{ Tingkat Kepuasan (\%) } \\
\cline { 3 - 6 } & & tidak & cukup & puas & sangat \\
\hline 1. & $\begin{array}{l}\text { Materi } \\
\text { kegiatan }\end{array}$ & 0,00 & 10,00 & 10,00 & 80,00 \\
2. & $\begin{array}{l}\text { Manfaat } \\
\text { program }\end{array}$ & 0,00 & 0,00 & 10,00 & 90,00 \\
3. $\quad \begin{array}{l}\text { Keberlanjutan } \\
\text { Program }\end{array}$ & 0,00 & 0,00 & 0,00 & 100,00 \\
\hline Rata-rata & 0,00 & 3,33 & 6,67 & 90,00 \\
\hline
\end{tabular}

Sumber: hasil evaluasi peserta

\section{Kesimpulan}

Kegiatan pengabdian masyarakat yang dilaksanakan di Desa Slateng Kecamatan Ledokombo Kabupaten Jember dalam menyelesaikan permasalahan produktifitas tanaman pada lahan dengan solum tanah yang dangkal dapat disimpulkan bahwa peserta terutama petani sangat puas dengan tingkat kepuasan $90 \%$ dengan program pengabdian masyarakat ini yang mampu memberi solusi dalam peningkatan produktifitas tanaman yang dibudidayakan terutama pada lahan marginal dengan solum tanah dangkal. Keberlanjutan program sangat puas dengan tingkat kepuasan $100 \%$.

\section{Daftar Pustaka}

Basuki, Benito Heru Purwanto, Bambang Hendro Sunarminto, Sri Nuryani, and Hidayah Utami. 2015. "Analisis Cluster Sebaran Hara Makro Dan Rekomendasi Pemupukan Untuk Tanaman Tebu ( Saccharum Officinarum Linn .) Cluster Analysis of Macro Nutrient Distribution and Fertilization Recommendations for Sugarcane ( Saccharum Officinarum Linn .).” 18(3):118-26.

Basuki, Basuki, and Vega Kartika Sari. 2020. "Efektifitas Dolomit Dalam Mempertahankan PH Tanah Inceptisol Perkebunan Tebu Blimbing Djatiroto." Buletin Tanaman Tembakau, Serat \& Minyak Industri 11(2):58. doi: 10.21082/btsm.v11n2.2019.58-64.

Basuki, Basuki, Sukron Romadhona, Listya Purnamasari, and Vega Kartika Sari. 2021. "Kemandirian Masyarakat Desa Sekarputih
Kecamatan Tegalampel Dalam Meningkatkan Kualitas Tanah Melalui Pembuatan Pupuk Organik Kotoran Sapi." SELAPARANG Jurnal Pengabdian Masyarakat Berkemajuan 5(1):981. doi: 10.31764/jpmb.v5i1.6699.

Basuki, Nurul Dwi Novikarumsari, Indah Ibanah, and Indri Fariroh. 2021. "Pemberdayaan Masyarakat Desa Sukamakmur Kabupaten Jember Dalam Budidaya Lobster Air Tawar."

Basuki, Sukron Romadhona, Vega Kartika Sari, and Iqbal Erdiansyah. 2021. "Karakteristik Iklim Dan Tanah Vulkanis Di Sisi Barat Gunung Api Ijen Jawa Timur Sebagai Dasar Penentu Pengelolaan Varietas Tanaman Padi ( Oriza Sativa L .) Climate Characteristics and Volcanic Soils on The West Side of Mount Ijen , East Java as The Basis." Jurnal Penelitian Pertanian Terapan 21(2):108-17.

BPS. 2021. "Pertanian Dan Pertambangan." Https://Jemberkab.Bps.Go.Id/.

Brahmantyo, Budi, and Bandono Salim. 2006. "Klasifikasi Bentuk Muka Bumi (Landform) Untuk Pemetaan Geomorfologi Pada Skala 1:25.000 Dan Aplikasinya Untuk Penataan Ruang." Jurnal Geoaplika 1(2):71-79. doi: 10.31227/osf.io/8ah6v.

Ratriyanto, Adi, Susi Dwi Widyawati, Wara P.S. Suprayogi, Sigit Prastowo, and Nuzul Widyas. 2019. "Pembuatan Pupuk Organik Dari Kotoran Ternak Untuk Meningkatkan Produksi Pertanian." SEMAR (Jurnal Ilmu Pengetahuan, Teknologi, Dan Seni Bagi Masyarakat) 8(1):9-13. doi: 10.20961/semar.v8i1.40204.

Sari, Vega Kartika, Basuki, Marga Mandala, Nurul Dwi Novikarumsari, and Iqbal Erdiansyah. 2021. "Pemberdayaan Masyarakat Desa Slateng Kecamatan Ledokombo Jember Mengolah Limbah Serbuk Gergaji Sengon Menjadi Biochar." 2-6.

Setiawati, T. C., Basuki, and Niken Sulistyawati. 2019. "Pengamatan Kesuburan Tanah, Pemanfaatan Organisme Tanah Untuk Pengendali Hama Uret Serta Perbaikan Manajemen Laboratorium Berbasis ISO 17025." Jurnal Pengabdian Masyarakat IPTEKS 5(2):176-81. 
Sukarman, Sukarman, Ai Dariah, and Suratman Suratman. 2020. "TANAH VULKANIK DI LAHAN KERING BERLERENG DAN POTENSINYA UNTUK PERTANIAN DI INDONESIA / Volcanic Soils in Sloping Dry Land and Its Potential for Agriculture in Indonesia." Jurnal Penelitian Dan Pengembangan Pertanian 39(1):21. doi: 10.21082/jp3.v39n1.2020.p21-34.

Sukri, M. Zayin, Refa Firgiyanto, Vega Kartika Sari, and Basuki Basuki. 2020. "Kombinasi Pupuk Kandang Sapi, Asam Humat Dan Mikoriza Terhadap Infeksi Akar Bermikoriza Tanaman Cabai Dan Ketersediaan Unsur Hara Tanah Udipsamments." Jurnal Penelitian Pertanian Terapan 19(2):142. doi: 10.25181/jppt.v19i2.1450.

Wardani, Corryati, Jamhari Jamhari, Suhatmini Hardyastuti, and Ani Suryantini. 2019. "Kinerja Ketahanan Beras Di Indonesia: Komparasi Jawa Dan Luar Jawa Periode 2005-2017." Jurnal Ketahanan Nasional 25(1):107. doi: 10.22146/jkn.41770.

Wibisono, Kuntadi. 2021. "JURNAL GEOGRAFI Monitoring Kinerja DAS Bedadung Kabupaten Jember , Jawa Timur." Jurnal Geografi 18(1):52-59. doi: 10.15294/jg.v18i1.25964. 